\title{
Fall Transplanting Improves Establishment of Balled and Burlapped Fringe Tree (Chionanthus virginicus $\mathbf{L}$.)
}

\author{
J. Roger Harris ${ }^{1}$, Patricia Knight ${ }^{2}$, and Jody Fanelli ${ }^{3}$ \\ Department of Horticulture, Virginia Polytechnic and State University, \\ Blacksburg, VA 24061
}

Additional index words. soil temperature, roots, root regeneration, landscape, irrigation

\begin{abstract}
The effect of fall vs. spring transplanting was tested on landscape-sized Chionanthus virginicus $L$. at a research farm in Blacksburg, Va. Two fall transplanting dates (11 Nov. and 1 Dec. 1994) were selected so that soil temperatures were decreasing and near $10^{\circ} \mathrm{C}$ for the earlier fall date (11 Nov.) and decreasing and near $5{ }^{\circ} \mathrm{C}$ for the later fall transplanting date $(1$ Dec.). The spring date (14 Mar. 1995) was selected so that soil temperatures were increasing and near $5^{\circ} \mathrm{C}$. All trees were transplanted with rootballs of native soil wrapped in burlap $(B \& B)$. Fringe tree was clearly tolerant of fall transplanting. Trees transplanted on 11 Nov. had a larger leaf area 1 month after bud set the next summer and had wider canopies and more dry mass of new roots at leaf drop than trees transplanted on the other dates. Trees transplanted on 14 Mar. had less total leaf area, leaf dry mass, and lower maximum root extension into the backfill soil than trees transplanted on 11 Nov. or 1 Dec. No root growth occurred beyond the original rootball until about early July (1 month after bud set) in any treatment, suggesting that first season posttransplant irrigation regimes need to focus on rootballs, not surrounding soil areas.
\end{abstract}

The establishment of transplanted trees depends on growth of existing intact roots and new roots that originate from severed roots into the backfill soil and the landscape beyond (Mullin, 1963; Ritchie and Dunlap, 1980). Fall transplanting of landscape trees may be a desirable practice if posttransplant root growth is well under way at spring budbreak, allowing a larger root system to more effectively support new shoot growth. Tree species vary in their response to fall transplanting, however. For example, Fraxinus pennsylvanica Marsh. (green ash) and Syringa reticulata (Blume) Hara (tree lilac) transplant successfully in the fall, but Quercus coccinea Muenchh. (scarlet oak) and Corylus colurna L. (Turkish hazelnut) do not (Harris and Bassuk, 1994). This variation is probably a result of differences among species in the ability of the harvested roots alone to adequately supply moisture to the tree until spring. Even though root growth continues on undisturbed trees, posttransplant root growth, when trees are transplanted bareroot in the fall (in upstate New York, USDA hardiness zone 5a), does not occur until after spring budbreak for Corylus colurna L. (Harris and Bassuk, 1994, 1995; Harris et al., 1994), probably as a result of immediate stress

Received for publication 16 Jan. 1996. Accepted for publication 25 July 1996 . The cost of publishing this paper was defrayed in part by the payment of page charges. Under postal regulations, this paper therefore must be hereby marked advertisement solely to indicate this fact.

${ }^{1}$ Assistant Professor.

${ }^{2}$ Graduate Student.

${ }^{3}$ Research Technician. from transplanting in the fall (transplant shock) and low soil temperatures in the spring. The initiation of spring budbreak is influenced by air temperature not soil temperature (Lyr and Garbe, 1995). Root extension on many temperate zone trees is severely limited when fall soil temperatures drop much below $10{ }^{\circ} \mathrm{C}$ (Harris et al., 1995; Headley and Bassuk, 1991; Lyr and Hoffmann, 1967). Therefore, an early spring in cold soil regions can induce budbreak before any new posttransplant root growth occurs, and stress on fall-transplanted trees may be exacerbated.

Differences in harvested root length may partly explain variation among species in tolerance to fall transplanting. Green ash and tree lilacs transplant successfully in the fall and have much more extensive root lengths within harvested rootballs than scarlet oak or Turkish hazelnut, which transplant with difficulty (Harris et al., 1994). Hydraulic resistance across roots increases at temperatures below $7{ }^{\circ} \mathrm{C}$ (Running and Reid, 1980). Increased root length within rootballs may be advantageous in such cold soil situations to allow enough hydration of the shoot system for survival during fall and winter.

The objective of our study was to determine whether new root growth before spring budbreak on fall-vs. spring-transplanted fringe tree is necessary for improved establishment of fall-transplanted trees. Fringe tree was selected because of the lack of any data on fall transplanting response of this species.

\section{Materials and Methods}

Plant material. On 11 Nov. 1994, treatments were randomly assigned to field-grown, multi-trunk (two to five stems per tree)
Chionanthus virginicus L. trees growing at the Urban Horticulture Center nursery near Virginia Tech in Blacksburg (USDA hardiness zone 6a). Mean height and width (SE of the mean in parentheses) were 106 (2.6) and 59 $(4.7) \mathrm{cm}$, respectively (width $=$ mean of width parallel to row direction and $90^{\circ}$ to row direction). Field soil type was Groseclose silt loam (claey, mixed, mesic Typic Hapludults) with pH 6.2 .

Treatments. Planting dates were chosen so that soil temperatures were low enough to likely limit new root growth throughout the time period between three transplant dates. Fall-transplanted trees, therefore, had much smaller root systems (i.e., the harvested rootball) throughout the winter than trees transplanted the following spring. Treatments included transplanting when soil temperatures were 1) decreasing and near $10^{\circ} \mathrm{C}$ (fall-transplanted), 2) decreasing and near $5^{\circ} \mathrm{C}$ (late falltransplanted), 3) increasing and near $5{ }^{\circ} \mathrm{C}$ (spring-transplanted), 4) trees not transplanted. Twelve single-plant replications were assigned to each of the three transplanting treatments and six to the nontransplanted treatment. Six trees from each of the three transplanting treatments were randomly assigned for evaluation of root regrowth at Spring 1995 budbreak (shoot extension $=1$ to $2 \mathrm{~cm}$ ). All other trees were assigned for evaluation at the end of the next growing season (Fall 1995). All trees were dug with $36-\mathrm{cm}$-diameter rootballs (American Association of Nurserymen, 1990) that were wrapped in copper sulfate-treated burlap (A.M. Leonard, Piqua, Ohio) and tightly laced with sisal twine. All harvested trees were transplanted into a nearby nursery row in a completely random statistical design within 2 $\mathrm{h}$ of harvesting. Planting holes were $\approx 75 \mathrm{~cm}$ wide and the depth of the rootball. Burlap and twine were left intact to facilitate harvest and data collection. After planting, all trees were individually flood irrigated. Backfill soil moisture was monitored thereafter, and trees were irrigated when necessary to maintain moist conditions. Transplant dates were 11 Nov. 1994, 1 Dec. 1994, and 14 Mar. 1995. Soil temperature was monitored with thermocouples placed 30 and $45 \mathrm{~cm}$ below the bare soil surface. The mean of the two measurements was the measurement for that day. Measurements were generally made at 1 - to 5-day intervals between 1300 and 1500 HR. The planting area was maintained free of weeds by hand pulling throughout the experiment.

Evaluation. Six trees from each of the three transplant dates were completely excavated and evaluated at budbreak (3 May 1995) for root regrowth beyond the original rootball. Since no roots had grown beyond the rootball and rootballs were intact, all trees were carefully replanted for evaluation at bud set (terminal buds present, 6 June 1995). Since no root growth was present beyond the original rootball at this date either, all trees were again gently replanted for evaluation $\approx 1$ month later. On 3 July, the same six trees were again completely excavated. All roots beyond the original rootball were removed and dried to a constant mass at $70{ }^{\circ} \mathrm{C}$ (dry mass). Leaves were re- 
moved from all excavated trees. Leaf area (LI 3000; LI-COR, Lincoln, Neb.), count, and dry mass were measured for each individual tree. On 20 Oct. 1995, height and width of all remaining trees (including nontransplanted trees) were recorded. This date corresponded with general fall coloration and the early stages of leaf drop. Transplanted trees were carefully excavated, and maximum root extension (mean of the four longest roots) beyond the rootball was recorded for each tree. Rootballs remained intact on all transplanted trees. All roots were then removed, back to the original rootball, and their dry mass was recorded. Evaluation of rootballs revealed no obvious restriction of root extension by the burlap. All data were subjected to analysis of variance. Mean separation among treatments was accomplished by the Waller-Duncan k ratio method (Ott, 1988).

\section{Results and Discussion}

The fall transplanting occurred when soil temperatures had just dropped below $10{ }^{\circ} \mathrm{C}$. Soil temperatures were soon in the range that has been shown to be unfavorable for root growth of many tree species (Harris et al., 1995; Headley and Bassuk, 1991; Lyr and Hoffmann, 1967). Although no data exist for fringe tree, soil temperatures likely were consistently low enough to restrict root growth for the entire 103 days between the late fall and the spring transplanting dates.

The fact that no root growth had occurred beyond the rootball by budbreak (3 May 1995) agrees with reports on transplanted trees in upstate New York (Harris and Bassuk, 1995) and Ohio (Struve and Joly, 1992). Since roots within the rootball were not examined, growth of intact roots that did not penetrate the burlap could not be assessed. However, regeneration from severed roots primarily takes place at the cut ends (Gilman and Yeager, 1988; Watson and Himelick, 1982; Wilcox, 1955), and root pruning stimulates the growth of existing laterals (Gilman and Yeager, 1988). New roots would probably quickly grow into the backfill soil since the severed tips of the old roots would be at the surface of the rootball and in close contact with the burlap covering, and existing lateral roots probably would be stimulated to quickly emerge from the rootball. Similar to fringe trees that were not transplanted, shoots of all transplanted trees grew quickly after budbreak for a short period, set buds, and never flushed again. A lack of an alternating pattern of shoot and root growth has been reported for roots $>1.0 \mathrm{~mm}$ in diameter on established trees (Harris et al., 1995) and for "long roots" on transplanted seedlings (Arnold and Struve, 1989). Shoot extension has also been negatively correlated with the number of roots regenerated from severed roots (Lee and Hackett, 1976). We found no observable root extension during shoot extension. However, excavation of rootballs 1 month later (3 July 1995) revealed the early stages of new root growth beyond the rootball. Root growth into the backfill soil was apparently just beginning since early extension was generally $3 \mathrm{~cm}$ or less beyond the intact burlap,

Table 1. Effects of transplant date on growth of balled and burlapped Chionanthus virginicus trees.

\begin{tabular}{|c|c|c|c|c|c|c|c|c|}
\hline $\begin{array}{l}\text { Transplant } \\
\text { date }\end{array}$ & $\begin{array}{c}\text { Early }^{\mathrm{z}} \\
\text { root } \\
\text { dry mass } \\
(\mathrm{g})\end{array}$ & $\begin{array}{c}\text { Late }^{\mathrm{y}} \\
\text { root } \\
\text { dry mass } \\
(\mathrm{g})\end{array}$ & $\begin{array}{c}\text { Max. }^{x} \\
\text { root } \\
\text { extension } \\
(\mathrm{cm})\end{array}$ & $\begin{array}{c}\text { Leaf }^{\mathrm{w}} \\
\text { area } \\
\left(\mathrm{m}^{2}\right)\end{array}$ & $\begin{array}{c}\text { Leaf } \\
\text { dry } \\
\text { mass } \\
(\mathrm{g})\end{array}$ & $\begin{array}{l}\text { Leaf } \\
\text { count }\end{array}$ & $\begin{array}{l}\text { Canopy } \\
\text { width } \\
\text { increase } \\
(\mathrm{cm})\end{array}$ & $\begin{array}{c}\mathrm{Ht} \\
\text { increase } \\
(\mathrm{cm})\end{array}$ \\
\hline $\begin{array}{l}11 \text { Nov. } 1994 \\
\text { (Fall) }\end{array}$ & $0.47 \mathrm{a}$ & $63.4 \mathrm{a}$ & $17.5 \mathrm{a}$ & $1.18 \mathrm{a}$ & $115 \mathrm{a}$ & 599 a & $22.5 \mathrm{a}$ & $13.3 \mathrm{~b}$ \\
\hline $\begin{array}{c}1 \text { Dec. } 1994 \\
\text { (late Fall) }\end{array}$ & $0.32 \mathrm{a}$ & $25.9 \mathrm{~b}$ & $15.2 \mathrm{a}$ & $0.93 \mathrm{~b}$ & 98 a & $405 \mathrm{a}$ & $14.3 \mathrm{~b}$ & $15.7 \mathrm{ab}$ \\
\hline $\begin{array}{l}14 \text { Mar. } 1995 \\
\text { (Spring) }\end{array}$ & $0.22 \mathrm{a}$ & $5.0 \mathrm{~b}$ & $9.1 \mathrm{~b}$ & $0.71 \mathrm{c}$ & $72 \mathrm{~b}$ & $399 \mathrm{a}$ & $8.1 \mathrm{~b}$ & $7.5 \mathrm{~b}$ \\
\hline Not transplanted & --- & --- & --- & --- & --- & --- & $27.0 \mathrm{a}$ & $23.0 \mathrm{a}$ \\
\hline
\end{tabular}

${ }^{2}$ Trees harvested on 3 July 1995. All roots outside of original rootball. Mean separation within columns by Waller-Duncan. $\mathrm{k}=100(\alpha=0.05) . \mathrm{n}=6$.

'Trees harvested on 20 Oct. 1995.

${ }^{x}$ Data represent mean of the four longest roots.

wTrees harvested on 3 July 1995.

"Trees harvested on 20 Oct. 1995.

although no differences in early root dry mass among treatments were apparent (Table 1). This finding has profound consequences for posttransplant management of fringe trees. Until new roots extend into the backfill soil, the reservoir of water available for uptake is only the harvested rootball. It is, therefore, very important to irrigate rootballs regularly well into the first growing season, even for fall-transplanted trees. Rootball moisture must be monitored often since no resources are available beyond the original rootball itself until well after full shoot extension.

Fall-transplanted trees had the largest root dry mass at the final excavation (20 Oct. 1995). Maximum root extension, total leaf area, and leaf dry mass were all less for springthan fall- or late fall-transplanted trees. Leaf count, however, was statistically similar among treatments. Canopy width increased similarly for fall-transplanted trees and trees that were never transplanted and more for late fall- or spring-transplanted trees. Height increase, however, was inconsistent.

Fringe trees clearly tolerate fall transplanting. Although survival was $100 \%$ at all three transplanting dates, these data show a distinct advantage to fall and late fall vs. spring transplanting, although soil temperatures were low enough to likely limit root growth before budbreak for all three transplanting dates. Both fall transplantings resulted in more posttransplant growth than the spring transplanting. Posttransplant establishment involves recovery from the physiological stresses imposed (Rietveld, 1989). The spring-transplanted trees had 103 and 123 fewer days for stress amelioration and acclimation before spring budbreak than fall- or late fall-transplanted trees, respectively. The physiological processes of root regrowth may have been well under way for fall-transplanted trees even though no roots had emerged from the rootballs. The increased first season growth after transplanting of falland late fall-transplanted fringe trees probably occurred because of this increased time available for acclimation compared to spring-transplanted trees. This study also clearly suggests the need for high levels of irrigation management during the first growing season after transplanting, because new root growth does not penetrate into the available backfill-soil water reservoir until late June.

Fringe tree has a very wide native distribution (Petrides, 1988), and its potential use as a nursery crop in diverse climates is great. Due to its slow growth and somewhat difficult propagation, fringe tree is very expensive, further stressing the importance of good transplanting technique for this desirable landscape tree.

\section{Literature Cited}

American Association of Nurserymen. 1990. American standard for nursery stock. Amer. Assn. Nurserymen, Washington, D.C.

Arnold, M.A. and D.K. Struve. 1989. Green ash establishment following transplant. J. Amer. Soc. Hort. Sci. 114:591-595.

Gilman, E.F. and T.H. Yeager. 1988. Root initiation in root-pruned hardwoods. HortScience 23:775

Harris, J.R. and N.L. Bassuk. 1994. Seasonal effects on transplantability of scarlet oak, green ash, Turkish hazelnut and tree lilac. J. Aboric. 20:310 317.

Harris, J.R. and N.L. Bassuk. 1995. Effects of defoliation and antitranspirant treatment on transplant response of scarlet oak, green ash and Turkish hazelnut. J. Aboric. 21:33-36.

Harris, J.R., N.L. Bassuk, and T.H. Whitlow. 1994. A window into below-ground growth of landscape trees: Implications for transplant success. HortTechnology 4:368-371.

Harris, J.R., N.L. Bassuk, R.W. Zobel, and T.H. Whitlow. 1995. Root and shoot growth periodicity of green ash, scarlet oak, Turkish hazelnut, and tree lilac. J. Amer. Soc. Hort. Sci. 120:211216.

Headley, D. and N. Bassuk. 1991. Effect of time of application of sodium chloride in the dormant season on selected tree seedlings. J. Environ. Hort. 9:130-136.

Lee, C.I. and W.P. Hackett. 1976. Root regeneration of transplanted Pistacia chinensis Bunge. seedlings at different growth stages. J. Amer. Soc. Hort. Sci. 101:236-240.

Lyr, H. and V. Garbe. 1995. Influence of root temperature on growth of Pinus sylvestris, Fagus sylvatica, Tilia cordata and Quercus robur. Trees 9:220-223.

Lyr, H. and G. Hoffmann. 1967. Growth rates and growth periodicity of tree roots. Intl. Rev. For. Res. 181-236.

Mullin, R.E. 1963. Planting check in spruce. For. Chron. 39:252-269.

Ott, L. 1988. An introduction to statistical methods and data analysis. 3rd ed. PWS-Kent, Boston. 
Petrides, G.A. 1988. A field guide to eastern trees. Houghton Mifflin, Boston.

Rietveld, W.J. 1989. Transplanting stress in bareroot conifer seedlings:Its development and progression to establishment. North. J. Appl. For. 6:99-107.

Ritchie, G.A. and J.R. Dunlap. 1980. Root growth potential: Its development and expression in forest tree seedlings. N. Z. J. For. Sci. 10:218248

Running, S. and C. Reid. 1980. Soil temperature influences on root resistance of Pinus contorta seedlings. Plant Physiol. 65:635-640.

Struve, D.K. and R.J. Joly. 1992. Transplanted red oak seedlings mediate transplant shock by re- ducing leaf surface area and altering carbon allocation. Can. J. For. Res. 22:1441-1448.

Watson, G.W. and E.B. Himelick. 1982. Seasonal variation in root regeneration of transplanted trees. J. Aboric. 8:305-310.

Wilcox, H. 1955. Regeneration of injured root systems in noble fir. Bot. Gaz. 116:221-234. 